\title{
EFFECT OF VERY HIGH LEVELS OF NITROGEN AND PHOSPOURS FERTILIZERS, PINCHING, AND SEED RATE SOWING ON GROWTH, SEED YIELD AND COMPONENTES OF Nigella sativa L. 2- SEED COMPENENTS
}

Yousif H. Hammo

Hort. Dept., College of Agriculture, Dohuk Univ., Iraq

\begin{abstract}
This field experiment was conducted during the season 2005-2006 in Singar - Mosul city to investigate the effects of very high level $\left(320 \mathrm{~N}, 300 \mathrm{P}_{2} \mathrm{O}_{5}\right)$ $\mathrm{kg} \mathrm{ha}^{-1}$, and high level $\left(280 \mathrm{~N}, 260 \mathrm{P}_{2} \mathrm{O}_{5}\right) \mathrm{kg} \mathrm{ha}^{-1}$ of nitrogen and phosphorus fertilizer, pinch and with out pinch, and plant seed rate sowing 0.6, 0.8, 1.0, 1.2 $\mathrm{g} / 10 \mathrm{~m}^{2}$ was done by hand within $3,4,5,6$ rows respectively in $(10) \mathrm{m}^{2}$ plot size on seed components of Nigella sativa $\mathrm{L}$. The experiment was laid out in randomized complete block design with three replications. The results include the following. Very high levels of nitrogen and phosphorus caused a significant increase in fixed oil, volatile oil, protein, and phosphorus; in contrast carbohydrate was significantly decreased, while humidity and ash cannot be affected with this factor. Pinching nigella plants causes a significantly increasing in fixed oil, ash, and carbohydrate of seeds while volatile oil, protein, and phosphorus were decreased significantly when compared with non pinched plants. Increased seed rate sowing from 0.8 to $1.2 \mathrm{~g} / 10 \mathrm{~m}^{2}$ caused significant increasing in fixed oil when compared with 0.6 $\mathrm{g} / 10 \mathrm{~m}^{2}$ while decreased seed rate sowing $0.6,0.8 \mathrm{~g} / 10 \mathrm{~m}^{2}$ caused significant increases in volatile oil and ash when compared with $1.0,1.2 \mathrm{~g} / 10 \mathrm{~m}^{2}$. Protein also Increased significantly from 20.67 to 24.40 with decreased seed rate sowing from 1.2 to $0.8 \mathrm{~g} / 10 \mathrm{~m}^{2}$. while medium rate cause significant increase in phosphorus when compared with lowest and highest rate, the lowest rate of see rate give the highest percentage of carbohydrate when compared with other .
\end{abstract}

\section{INTRODUCTION}

Nigella (Nigella sativa L.) is an annual herbaceous plant belonging to the family Ranunculacea. It is grown in Mediterranean region and widely cultivated throughout South Europe, Syria, Egypt, Saudi Arabia, Iraq, Iran, India and Turkey (Al-Dagawi, 1996). Mature seeds are consumed for edible purposes as seasoning for vegetables, legumes and different types of baked products (Atta, 2003). Also its seeds are used in folk medicine as a natural stimulant of immunity, anti-allergic, asthma, treatment of neurological and skin diseases, anti-inflammatory cough, analgesic, diuretic, anti-diabetic, (Al-Dagawi , 1996; Tierra, 2002). Nitrogen which is a major component of proteins, hormones, chlorophyll, vitamins and enzymes is a major factor in stem and leaf growth. Also phosphorus is necessary for photosynthesis, protein formation and almost all aspects of growth and metabolism in plants. It is essential for flower and fruit formation. (Wikipedia, 2007). Ahmed (1997) found that fertilize Nigella sativa plants with triple calcium super phosphate $(48,96,142) \mathrm{P}_{2} \mathrm{O}_{5} \mathrm{ha}^{-1}$ caused a significant increase in fixed and volatile percentage and decrease carbohydrate content of the herb of nigella. Hammo and 
Al-Atrakchii (2006) on Nigella sativa found that increase

Received / 13 / $10 / 2007$ accepted /30/1/2008

fertilizer levels of nitrogen and phosphorus to $240 \mathrm{~kg} \mathrm{~N}$ and $220 \mathrm{~kg} \mathrm{P}_{2} \mathrm{O}_{5} \mathrm{ha}^{-1}$ causes significant increases in seeds contains of volatile oil, phosphorus except total carbohydrate which decreased in the first season and phosphorus and humidity in the second season. Hand pinching (the removal of the apical bud of the main shoot) is a common floricultural practice (Ecke and Matkin, 1976) designed to encourage auxiliary shoot development and increasing flower number for display purposes (Love, 1975; Larson, 1980). Al-khatony (2003) on nigella sativa obtained that protein, and phosphorus decreased significantly when pinched while total carbohydrate and ash increased. Seed rate is the key factor determining effecting the yield and yield components. Toncer and Kizil (2004) found that sowing Nigella plant with seed rate $(10,20,30,40 \& 50) \mathrm{kg} \mathrm{ha}^{-1}$ under semi arid conditions in Diyarbakir significantly affected plant height, number of branch per plant, number of capsule per plant, seed yield per plant and seed yield but did not affected essential oil and fatty oil rate. Naghdi et al. (2000) obtained that planting space and seasonal variation have significant effect on quality and rows of $50 \mathrm{~cm}$ apart quantity yield of thyme plant when cultivated in rows of $50 \mathrm{~cm}$ apart with inter row spacing of 15,30 , and $45 \mathrm{~cm}$, maximum yields of dry and wet herbage, volatile oil and thymol were obtained in $15 \mathrm{~cm}$. Because of the high response of nigella plant to high level of nitrogen and phosphorus ( $240 \mathrm{~N} \mathrm{~kg}, 220 \mathrm{~kg} \mathrm{P}_{2} \mathrm{O}_{5} \mathrm{ha}^{-1}$ ) as shown in previous study (Hammo and Al-Atrakchii (2006) this study were done to clarify the influence of very high levels of fertilizers, seed rate sowing, and pinching on vegetative growth and seed yield of it.

\section{MATERIALS AND METHODS}

The field experiment was conducted during the season 2005-2006 in Singar / Mosul city to investigate the effects of some agricultural factors on vegetative growth and seed yield of Nigella sativa L. Seeds of Nigella sativa were obtained from the herbal market in Mosul, Iraq. The crop was sowed at 10 October 2005 in seed rate Sowing 0.6, 0.8, 1.0, $1.2 \mathrm{~g} / \mathrm{plot}\left(10 \mathrm{~m}^{2}\right.$ area) by hand within 3, 4, 5, 6 rows for each seed rate respectively, pinch and with out pinch plants were fertilized with two levels of nitrogen and phosphorus fertilizer very high level (320 $\left.\mathrm{N}, 300 \mathrm{P}_{2} \mathrm{O}_{5}\right) \mathrm{kg} \mathrm{ha}^{-1}$, and high level $\left(280 \mathrm{~N}, 260 \mathrm{P}_{2} \mathrm{O}_{5}\right) \mathrm{kg} \mathrm{ha}^{-1}$. All plants received $60 \mathrm{~kg} \mathrm{ha}^{-1}$ potassium fertilizers as potassium sulfate. Weeds were controlled by hand and all agriculture practices were done as needed. Harvesting was done on 15 June 2005 manually by pulling the dry plants out of the soil. Fixed oil percentage in seeds was calculated after extraction with Soxhlet Extraction Method (A O A C, 1980), volatile oil was determined by Modified Clevenger Method which described by Ranganna (1985)، Protein determine with MicroKjeldahl Method (A O A C, 1980) while phosphorus determine by Matt (1975) by use of Spectrophotometer which was also used to determine the total carbohydrate (Herbert et al. 1971). Humidity percentage determine by toloin which named Immiscible solvent distillation method which described by Ranganna (1985) . Ash percentage was determines with methods describe by Ranganna (1985).All 
data obtained were analyzed and compared statistically at a significance level of $5 \%$, by using SAS program (SAS, 1989-1996).

\section{RESULTS AND DISCUSSION}

Fixed oil percentage: Data presented in table (1) appear that very high level of fertilizer $\left(320 \mathrm{~N}, 300 \mathrm{P}_{2} \mathrm{O}_{5}\right) \mathrm{kg} \mathrm{ha}^{-1}$ lead to significantly increased in fixed oil percentage when compared with high level of fertilizer $\left(280 \mathrm{~N}, 260 \mathrm{P}_{2} \mathrm{O}_{5}\right) \mathrm{kg}^{-} \mathrm{h}^{-}$ ${ }^{1}$ and the percentage reached $41.52 \%, 40.79 \%$, respectively. This may be refer to nitrogen which plant require in large amounts and its role in almost all plant metabolic processes so its effect on promotes rapid growth, increases leaf size and quality, hastens crop maturity, and promotes fruit and seed development. Or may be related to phosphorus which aids in root development, flower initiation, and seed and fruit development (Tucker, 1999; Uchida, 2000). Pinching causes significantly increased in this character $41.65 \%$ when compared with non pinching $40.66 \%$, these results are in agreement with those which found by Cavins (2003), and Abdullah (2006). Although $0.8 \mathrm{~g} / 10 \mathrm{~m}^{2}$ of seed rate sowing hadn't any difference in fixed oil percentage $41.49 \%$ when compared with $1.2,1.0 \mathrm{~g} / 10 \mathrm{~m}^{2} 41.70 \%, 41.20$ respectively they differ significantly with the rate $0.6 \mathrm{~g} / 10 \mathrm{~m}^{2}$. These results are in agreement with Hammo and Al-Atrakchii (2006) and the reason may be related to increase the exposure area to sun shin so increasing dry speed which turns effect on

Table (1): Effect of very high levels of nitrogen and phosphorus fertilization, pinching, and Seed rate sowing on fixed oil percentage of Nigella sativa L. seeds.

\begin{tabular}{|c|c|c|c|c|c|c|c|}
\hline \multirow{2}{*}{$\begin{array}{c}\text { Fertilizer } \\
\text { Levels }\end{array}$} & \multirow{2}{*}{ Pinch } & \multicolumn{4}{|c|}{ Seed sowing rate $\mathrm{g} / 10 \mathrm{~m}^{2}$} & \multirow{2}{*}{$\begin{array}{c}\text { Fertilizer } \\
\times \text { pinch }\end{array}$} & \multirow{2}{*}{$\begin{array}{c}\text { Fertilizer } \\
\text { effect }\end{array}$} \\
\hline & & 1.2 & 1.0 & 0.8 & 0.6 & & \\
\hline \multirow{2}{*}{$\begin{array}{l}\text { Very } \\
\text { High }\end{array}$} & Pinch & $40.98 d-f$ & $42.73 \mathrm{ab}$ & $42.24 b c$ & $43.53 \mathrm{a}$ & $42.37 \mathrm{a}$ & \multirow{2}{*}{$41.52 \mathrm{a}$} \\
\hline & Without & $40.72 \mathrm{e}-\mathrm{g}$ & $41.74 b-e$ & $40.19 \mathrm{f}-\mathrm{h}$ & $40.06 \mathrm{f}-\mathrm{h}$ & $40.68 b$ & \\
\hline \multirow{2}{*}{ High } & Pinch & $41.64 c-e$ & $39.60 \mathrm{~h}$ & $41.55 \mathrm{c}-\mathrm{e}$ & $40.95 \mathrm{~d}-\mathrm{f}$ & $40.94 b$ & \multirow{2}{*}{$40.79 b$} \\
\hline & Without & $40.11 \mathrm{f}-\mathrm{h}$ & $41.90 b-d$ & $40.84 d-g$ & $39.75 \mathrm{gh}$ & $40.65 b$ & \\
\hline \multirow{2}{*}{$\begin{array}{c}\text { Fertilizer } \\
\times \\
\text { Seed rate } \\
\text { sowing } \\
\end{array}$} & $\begin{array}{l}\text { Very } \\
\text { High }\end{array}$ & $40.85 \mathrm{~cd}$ & $42.23 \mathrm{a}$ & $41.21 b c$ & $41.79 \mathrm{ab}$ & \multirow{2}{*}{\multicolumn{2}{|c|}{$\begin{array}{l}\text { Pinch } \\
\text { effect }\end{array}$}} \\
\hline & High & $40.88 \mathrm{~cd}$ & $40.75 \mathrm{~cd}$ & $41.20 \mathrm{bc}$ & $40.35 d$ & & \\
\hline \multirow{2}{*}{$\begin{array}{c}\text { Pinch } \\
\times \\
\text { Seed rate } \\
\text { sowing }\end{array}$} & Pinch & $41.31 \mathrm{~b}$ & $41.16 b c$ & 41.89ab & $42.24 \mathrm{a}$ & \multicolumn{2}{|c|}{$41.65 \mathrm{a}$} \\
\hline & Without & $40.41 \mathrm{~d}$ & $41.82 \mathrm{ab}$ & $40.52 \mathrm{~cd}$ & $39.91 d$ & \multicolumn{2}{|c|}{$40.66 \mathrm{~b}$} \\
\hline \multicolumn{2}{|c|}{ Seed rate sowing } & $40.86 \mathrm{~b}$ & $41.49 \mathrm{a}$ & $41.20 \mathrm{ab}$ & $41.07 \mathrm{ab}$ & & \\
\hline
\end{tabular}

Each means in row for one or interactions factors with different letters are significantly different at $\mathrm{P}=0.05$ using Duncan's multiple range test.

the elements absorption then decreases fixed oil percentage. All dual and triple interaction between factors levels have a significant influence on this character and the highest percentage $43.53 \% \mathrm{~cm}$ obtained in pinching plants fertilized with very high level of nitrogen and phosphorus and sowing at seed rate $1.2 \mathrm{~g} / 10 \mathrm{~m}^{2}$ 
while the lowest $39.60 \%$ for pinched plant fertilized with high level and sowing at $0.8 \mathrm{~g} / 10 \mathrm{~m}^{2}$.

Volatile oil percentage: very high level of fertilizer in table (2) showed significant increased in volatile oil percentage $0.923 \%$ when compared with high level $0.856 \%$. The reason may be refer to nitrate and phosphate availability which promote some metabolic processes such as cell division, cell enlargement and causes lateral root formation, elongation, promotes aerial vegetative growth, increases the top/root ratio, essential for fruit and seed formation so affects both yield and quality characteristics of vegetable production (Bates and Lynch, 1996; George, 2000; Okeno, 2002 ), also very high Phosphorus is important in plant bioenergetics as a component of ATP during photosynthesis Since ATP can be used for the biosynthesis of many plant bimolecular, also its use to modify the activity of various enzymes by phosphorylation. Pinching caused significant decrease in volatile percentage $0.879 \%$ when compared with non pinching $0.900 \%$. Low seed rate $0.6,0.8$ $\mathrm{g} / 10 \mathrm{~m}^{2}$ showed significant increased in volatile oil percentage $0.913 \%, 0.911 \%$ respectively when compared with $1.0,1.2 \mathrm{~g} / 10 \mathrm{~m}^{2} 0.868 \%, 0.865 \%$, respectively These results are in agreement with Hammo and Al-Atrakchii (2006) and the reason may be relate to Intra-specific competition which created as a result of high seed rate sowing so effect vegetetive growth which turns effect oil percentage and other character (K1z1l, 2002). All dual and triple interaction have significant influence on this character and the highest percentage $0.960 \%$ obtained in non pinching plants fertilized with very high level of nitrogen and phosphorus and sowing at seed rate $0.8 \mathrm{~g} / 10 \mathrm{~m}^{2}$ while the lowest $0.820 \%$ for pinched plant fertilized with high level and sowing at 1.2 $\mathrm{g} / 10 \mathrm{~m}^{2}$ rate.

Table(2): Effect of very high levels of nitrogen and phosphorus fertilization, pinching, and Seed rate sowing on volatile oil percentage of Nigella sativa L. seeds.

\begin{tabular}{|c|c|c|c|c|c|c|c|}
\hline \multirow{2}{*}{$\begin{array}{c}\text { Fertilizer } \\
\text { Levels }\end{array}$} & \multirow{2}{*}{ Pinch } & \multicolumn{4}{|c|}{ Seed sowing rate $\mathrm{g} / 10 \mathrm{~m}^{2}$} & \multirow{2}{*}{$\begin{array}{c}\text { Fertilizer } \\
\times \text { pinch }\end{array}$} & \multirow{2}{*}{$\begin{array}{c}\text { Fertilizer } \\
\text { effect }\end{array}$} \\
\hline & & 1.2 & 1.0 & 0.8 & 0.6 & & \\
\hline \multirow{2}{*}{$\begin{array}{l}\text { Very } \\
\text { High }\end{array}$} & Pinch & $0.940 \mathrm{ab}$ & $0.933 \mathrm{ab}$ & $0.893 b-d$ & $0.883 b-e$ & $0.913 a$ & \multirow{2}{*}{$0.923 \mathrm{a}$} \\
\hline & Without & $0.957 \mathrm{a}$ & $0.960 \mathrm{a}$ & $0.907 a-c$ & $0.910 \mathrm{a}-\mathrm{c}$ & $0.933 a$ & \\
\hline \multirow{2}{*}{ High } & Pinch & $0.870 c-f$ & $0.863 c-f$ & $0.827 \mathrm{ef}$ & $0.820 \mathrm{f}$ & $0.845 b$ & \multirow{2}{*}{$0.856 b$} \\
\hline & Without & $0.887 \mathrm{~b}-\mathrm{d}$ & $0.887 b-d$ & $0.847 d-f$ & $0.847 d-f$ & $0.867 \mathrm{~b}$ & \\
\hline \multirow{2}{*}{$\begin{array}{c}\text { Fertilizer } \\
\times \\
\text { Seed rate } \\
\text { sowing }\end{array}$} & $\begin{array}{l}\text { Very } \\
\text { High }\end{array}$ & $0.948 \mathrm{a}$ & $0.947 \mathrm{a}$ & $0.900 \mathrm{~b}$ & $0.897 b$ & \multirow{2}{*}{\multicolumn{2}{|c|}{$\begin{array}{l}\text { Pinch } \\
\text { effect }\end{array}$}} \\
\hline & High & $0.878 b$ & $0.875 b$ & $0.837 \mathrm{c}$ & $0.833 \mathrm{c}$ & & \\
\hline \multirow{2}{*}{$\begin{array}{c}\text { Pinch } \\
\times \\
\text { Seed rate } \\
\text { sowing } \\
\end{array}$} & Pinch & $0.905 \mathrm{ab}$ & $0.898 \mathrm{a}-\mathrm{c}$ & $0.860 \mathrm{~cd}$ & $0.852 \mathrm{~d}$ & \multicolumn{2}{|c|}{$0.879 b$} \\
\hline & Without & $0.922 \mathrm{a}$ & $0.923 \mathrm{a}$ & $0.877 \mathrm{~b}-\mathrm{d}$ & $0.878 b-d$ & \multicolumn{2}{|c|}{$0.900 \mathrm{a}$} \\
\hline \multicolumn{2}{|c|}{ Seed rate sowing } & $0.913 a$ & $0.911 \mathrm{a}$ & $0.868 \mathrm{~b}$ & $0.865 b$ & & \\
\hline
\end{tabular}

Each means in row for one or interactions factors with different letters are significantly different at $\mathrm{P}=0.05$ using Duncan's multiple range test. 
Protein percentage: Very high level of nitrogen and phosphorus demonstrate significant effect on protein percentage in seeds as shown in table (3) when compared with high level and the values for the two levels reached $23.49 \%$, $20.07 \%$ respectively. these results are in agreement with El-Gamassy et al. (1980) how found that increasing nitrogen and phosphorus fertilizer to (714 calcium nitrite, 714 potassium super phosphate) $\mathrm{kg} \mathrm{ha}^{-1}$ cause an increases in nitrogen, phosphorus, and oil percentage in leaves of Majorana hortensis. The reason may be refer to increase absorption and accumulation of nitrogen in plant tissue then seeds as a result to roots and vegetative strong growth (AlKhfagi, 1986). Pinching cause significantly decreased in this character $20.02 \%$ when compared with non pinching $23.55 \%$ and the result may be relate to significant effect of pinch in increased the number of lateral shoot development as shown in part one of this study which is stimulated and promoted by hand pinching then increased the competition between seeds (Asiah et al. 1992; Phetpradap et al. 1994). Decreased seed rate sowing from 1.2 to $0.8 \mathrm{~g} / 10 \mathrm{~m}^{2}$ caused significant increased in protein percentages from $20.67 \%$ to $24.40 \%$ then decreased suddenly to $18.83 \%$ when sowing at seed rate $0.6 \mathrm{~g} / 10 \mathrm{~m}^{2}$. This may be due to increase the exposure area to sun shin so increase dry speed of soil surface which turns affect elements absorption then decrease protein percentage. Kizil (2002) reported that high seed rate created higher interplant competition. All dual and third interaction between the levels of factors had a significant influences on this character and the highest percentage $28.25 \%$ obtained in non pinching plants fertilized with very high level of nitrogen and phosphorus and sowing at seed rate $0.8 \mathrm{~g} / 10 \mathrm{~m}^{2}$ while the lowest $17.00 \%$ for pinched plant fertilized with high level and sowing at 1.0 , and $1.2 \mathrm{~g} / 10 \mathrm{~m}^{2}$ rate.

Table(3): Effect of very high levels of nitrogen and phosphorus fertilization, pinching, and Seed rate sowing on protein percentage Nigella sativa $\mathrm{L}$. seeds.

\begin{tabular}{|c|c|c|c|c|c|c|c|}
\hline \multirow{2}{*}{$\begin{array}{c}\text { Fertilizer } \\
\text { Levels }\end{array}$} & \multirow{2}{*}{ Pinch } & \multicolumn{4}{|c|}{ Seed sowing rate $\mathrm{g} / 10 \mathrm{~m}^{2}$} & Fertilizer & Fertilizer \\
\hline & & 1.2 & 1.0 & 0.8 & 0.6 & $\times$ pinch & effect \\
\hline \multirow{2}{*}{$\begin{array}{l}\text { Very } \\
\text { High }\end{array}$} & Pinch & $18.25 \mathrm{ef}$ & $26.71 \mathrm{ab}$ & $23.89 \mathrm{c}$ & $21.06 \mathrm{~d}$ & $22.48 \mathrm{~b}$ & \multirow{2}{*}{$23.49 \mathrm{a}$} \\
\hline & Without & $19.92 \mathrm{de}$ & $28.25 \mathrm{a}$ & $26.25 \mathrm{ab}$ & $23.63 \mathrm{c}$ & $24.51 \mathrm{a}$ & \\
\hline \multirow{2}{*}{ High } & Pinch & $17.00 \mathrm{f}$ & $18.65 \mathrm{ef}$ & $17.58 \mathrm{f}$ & $17.00 \mathrm{f}$ & $17.56 \mathrm{c}$ & \multirow{2}{*}{$20.07 \mathrm{~b}$} \\
\hline & Without & $20.17 \mathrm{de}$ & $24.00 \mathrm{c}$ & $25.17 \mathrm{bc}$ & $21.00 \mathrm{~d}$ & $22.58 \mathrm{~b}$ & \\
\hline \multirow{2}{*}{$\begin{array}{c}\text { Fertilizer } \\
\times \\
\text { Seed rate } \\
\text { sowing }\end{array}$} & $\begin{array}{l}\text { Very } \\
\text { High }\end{array}$ & $19.08 \mathrm{~d}$ & $27.48 \mathrm{a}$ & $25.07 \mathrm{~b}$ & $22.34 \mathrm{c}$ & \multirow{2}{*}{\multicolumn{2}{|c|}{$\begin{array}{l}\text { pinch } \\
\text { effect }\end{array}$}} \\
\hline & High & $18.58 \mathrm{~d}$ & $21.32 \mathrm{c}$ & $21.38 \mathrm{c}$ & $19.00 \mathrm{~d}$ & & \\
\hline \multirow{2}{*}{$\begin{array}{c}\text { Pinch } \\
\times \\
\text { Seed rate } \\
\text { sowing } \\
\end{array}$} & Pinch & $17.63 \mathrm{e}$ & $22.68 \mathrm{~b}$ & $20.74 \mathrm{c}$ & $19.03 \mathrm{~d}$ & \multicolumn{2}{|c|}{$20.02 \mathrm{~b}$} \\
\hline & Without & $20.04 \mathrm{~cd}$ & $26.13 \mathrm{a}$ & $25.71 \mathrm{a}$ & $22.31 \mathrm{~b}$ & \multicolumn{2}{|c|}{$23.55 \mathrm{a}$} \\
\hline \multicolumn{2}{|c|}{ Seed rate sowing } & $18.83 \mathrm{~d}$ & $24.40 \mathrm{a}$ & $23.22 \mathrm{~b}$ & $20.67 \mathrm{c}$ & & \\
\hline
\end{tabular}

Each means in row for one or interactions factors with different letters are significantly different at $\mathrm{P}=0.05$ using Duncan's multiple range test. 
Phosphorus percentage: Very high level of nitrogen and phosphorus showed significant effect on phosphorus percentage in seeds as shown in table (4) when compared with high level and the values for the two levels reach $0.622 \%$, $0.577 \%$ respectively. These results are in agreement with those reported by Hanafy (1984) on Coriandrum sativum how found that increasing phosphorus fertilizer lead to increase in phosphorus and decreased in carbohydrate content. Pinching cause significantly decreased in this character $0.536 \%$ when compared with non pinching 0.663 (Previously mentioned reasons in previous character). Third seed rate sowing caused significant increased in phosphorus percentages $0.628 \%$ when compared with the lowest $0.6 \mathrm{~g} / 10 \mathrm{~m}^{2}$ and highest $1.2 \mathrm{~g} / 10 \mathrm{~m}^{2}$ seed rate sowing $0.561 \%$ and $0.598 \%$ respictivly. (Previously mentioned reasons in previous character). All interaction between the levels of studied factors have a significant influence on this characters and the highest percentage $0.743 \%$ obtained in non pinching fertilized with very high level of nitrogen and phosphorus and sowing at seed rate $0.8 \mathrm{~g} / 10 \mathrm{~m}^{2}$ while the lowest $0.476 \%$ for pinched plant fertilized with high level and sowing at $0.8 \mathrm{~g} / 10 \mathrm{~m}^{2}$ rate.

Table (4): Effect of very high levels of nitrogen and phosphorus fertilization, pinching, and Seed rate sowing on phosphorus Nigella sativa L. seeds.

\begin{tabular}{|c|c|c|c|c|c|c|c|}
\hline \multirow{2}{*}{$\begin{array}{c}\text { Fertilizer } \\
\text { Levels }\end{array}$} & \multirow{2}{*}{ Pinch } & \multicolumn{4}{|c|}{ Seed sowing rate $\mathrm{g} / 10 \mathrm{~m}^{2}$} & \multirow{2}{*}{$\begin{array}{c}\text { Fertilizer } \\
\times \text { pinch }\end{array}$} & \multirow{2}{*}{$\begin{array}{c}\text { Fertilizer } \\
\text { effect }\end{array}$} \\
\hline & & 1.2 & 1.0 & 0.8 & 0.6 & & \\
\hline \multirow{2}{*}{$\begin{array}{l}\text { Very } \\
\text { High } \\
\end{array}$} & Pinch & $0.556 \mathrm{e}-\mathrm{g}$ & $0.552 \mathrm{e}-\mathrm{g}$ & 0.574 ef & 0.571 ef & $0.563 \mathrm{c}$ & \multirow{2}{*}{$0.622 \mathrm{a}$} \\
\hline & Without & $0.691 \mathrm{bc}$ & $0.743 \mathrm{a}$ & $0.719 \mathrm{ab}$ & 0.569 ef & $0.681 \mathrm{~b}$ & \\
\hline \multirow[b]{2}{*}{ High } & Pinch & $0.504 \mathrm{hi}$ & $0.476 \mathrm{i}$ & $0.532 \mathrm{f}-\mathrm{h}$ & $0.524 \mathrm{gh}$ & $0.509 \mathrm{~d}$ & \multirow{2}{*}{$0.577 \mathrm{~b}$} \\
\hline & Without & $0.640 \mathrm{~d}$ & $0.672 \mathrm{~cd}$ & $0.687 \mathrm{bc}$ & $0.581 \mathrm{e}$ & $0.645 \mathrm{a}$ & \\
\hline \multirow{2}{*}{$\begin{array}{c}\text { Fertilizer } \\
\times \\
\text { Seed rate } \\
\text { sowing }\end{array}$} & $\begin{array}{l}\text { Very } \\
\text { High } \\
\end{array}$ & $0.623 \mathrm{ab}$ & $0.648 \mathrm{a}$ & $0.646 \mathrm{~b}$ & $0.570 \mathrm{c}$ & \multirow{2}{*}{\multicolumn{2}{|c|}{$\begin{array}{l}\text { pinch } \\
\text { effect }\end{array}$}} \\
\hline & High & $0.572 \mathrm{c}$ & 0.5 & 0.6 & $0.552 \mathrm{c}$ & & \\
\hline \multirow{2}{*}{$\begin{array}{c}\text { Pinch } \\
\times \\
\text { Seed rate } \\
\text { sowing }\end{array}$} & Pinch & $0.530 \mathrm{de}$ & $0.514 \mathrm{e}$ & $0.553 \mathrm{~cd}$ & $0.54 \mathrm{~cd}$ & \multicolumn{2}{|c|}{$0.536 \mathrm{~b}$} \\
\hline & Without & $0.666 \mathrm{~b}$ & 0.707 & $0.703 \mathrm{a}$ & $0.575 \mathrm{c}$ & \multicolumn{2}{|c|}{$0.663 \mathrm{a}$} \\
\hline \multicolumn{2}{|c|}{ Seed rate sowing } & $0.598 \mathrm{~b}$ & $0.611 \mathrm{ab}$ & $0.628 \mathrm{a}$ & $0.561 \mathrm{c}$ & & \\
\hline
\end{tabular}

Each means in row for one or interactions factors with different letters are significantly different at $\mathrm{P}=0.05$ using Duncan's multiple range test.

Total carbohydrate percentage: Very high level of nitrogen and phosphorus indicate significant decreased in total carbohydrate percentage $25.49 \%$ as shown in table (5) when compared with high level $28.65 \%$. These results are in agreement with Hanafy (1984) and Hammo and Al-Atrakchii (2006). This may be revert to the role of phosphorus in carbohydrate metabolism to product ATP unit which use in create turpentine compound so cause increase in oil and decrease in carbohydrate (Goodwin and Mercer, 1985; kamel et al. 1989). Pinching cause significantly increased in this character $28.50 \%$ when compared with non pinched $25.64 \%$. All seed rate sowing haven't any significant 
increased in this character $28.06 \%, 26.42 \%, 27.92 \%$ for $0.6,1.0,1.2 \mathrm{~g} / 10 \mathrm{~m}^{2}$ respectively except $0.8 \mathrm{~g} / 10 \mathrm{~m}^{2}$ which decreased significantly when compared and reach $25.89 \%$. All interaction have significant influence on this character and the highest percentage $31.71 \%$ obtained in pinching plants fertilized with high level of nitrogen and phosphorus and sowing at seed rate $0.8 \mathrm{~g} / 10 \mathrm{~m}^{2}$ while the lowest $21.16 \%$ for non pinched plant fertilized with very high level and sowing at $0.8 \mathrm{~g} / 10 \mathrm{~m}^{2}$.

Humidity percentage: Data in table (6) demonstrate that very high and high levels of nitrogen and phosphorus fertilizer, pinch, with out pinch, all seed rate sowing, and all dual and third interaction between these factors haven't any significant effect on this character. The means of data ranged between (4.63 4.93) \% these results are in agreement with (Hanafy, 1984; AL-Kaisey et al. 1999).

Ash percentage: Although very high and high levels of nitrogen and phosphorus fertilizer had no any significant effect on ash percentage as shown in table (7). Pinching cause significantly increased in this character $4.87 \%$ when compared with

Table (5): Effect of very high levels of nitrogen and phosphorus fertilization, pinching, and Seed rate sowing on total carbohydrate percentage of Nigella sativa L. seeds.

\begin{tabular}{|c|c|c|c|c|c|c|c|}
\hline \multirow{2}{*}{$\begin{array}{c}\text { Fertilizer } \\
\text { Levels }\end{array}$} & \multirow{2}{*}{ Pinch } & \multicolumn{4}{|c|}{ Seed sowing rate $\mathrm{g} / 10 \mathrm{~m}^{2}$} & \multirow{2}{*}{$\begin{array}{c}\text { Fertilizer } \\
\times \text { pinch }\end{array}$} & \multirow{2}{*}{$\begin{array}{c}\text { Fertilizer } \\
\text { effect }\end{array}$} \\
\hline & & 1.2 & 1.0 & 0.8 & 0.6 & & \\
\hline \multirow{2}{*}{$\begin{array}{l}\text { Very } \\
\text { High }\end{array}$} & Pinch & $27.23 \mathrm{~b}-\mathrm{e}$ & $25.21 \mathrm{ef}$ & 27.69 a-e & $26.13 \mathrm{c}-\mathrm{f}$ & $26.57 \mathrm{~b}$ & \multirow{2}{*}{$25.49 \mathrm{~b}$} \\
\hline & Without & $27.30 \mathrm{~b}-\mathrm{e}$ & $21.16 \mathrm{~g}$ & $22.46 \mathrm{fg}$ & $26.77 \mathrm{~b}-\mathrm{e}$ & $24.42 \mathrm{c}$ & \\
\hline \multirow{2}{*}{ High } & Pinch & $30.26 \mathrm{a}-\mathrm{c}$ & $31.71 \mathrm{a}$ & $30.75 \mathrm{ab}$ & $29.03 \mathrm{a}-\mathrm{e}$ & $0.44 \mathrm{a}$ & \multirow{2}{*}{$28.65 \mathrm{a}$} \\
\hline & Without & $27.45 \mathrm{~b}-\mathrm{e}$ & $25.47 \mathrm{~d}-\mathrm{f}$ & $24.77 \mathrm{e}-\mathrm{g}$ & $29.74 \mathrm{a}-\mathrm{d}$ & $5.86 \mathrm{~b}$ & \\
\hline \multirow{2}{*}{$\begin{array}{c}\text { Fertilizer } \\
\times \\
\text { Seed rate } \\
\text { sowing } \\
\end{array}$} & $\begin{array}{l}\text { Very } \\
\text { High } \\
\end{array}$ & $\mathrm{ab}$ & $23.19 \mathrm{c}$ & $\mathrm{cc}$ & 26.4 & \multirow{2}{*}{\multicolumn{2}{|c|}{$\begin{array}{l}\text { pinch } \\
\text { effect }\end{array}$}} \\
\hline & High & $28.84 \mathrm{a}$ & $28.59 \mathrm{a}$ & $27.76 \mathrm{ab}$ & $29.39 \mathrm{a}$ & & \\
\hline \multirow{2}{*}{$\begin{array}{c}\text { Pinch } \\
\times \\
\text { Seed rate } \\
\text { sowing } \\
\end{array}$} & Pinch & $28.75 \mathrm{~b}$ & $28.46 \mathrm{a}$ & $29.22 \mathrm{a}$ & $27.58 \mathrm{a}$ & \multicolumn{2}{|c|}{$28.50 \mathrm{a}$} \\
\hline & $\mathrm{Wi}$ & 27 & 23. & 23. & 28. & \multicolumn{2}{|c|}{$25.64 \mathrm{~b}$} \\
\hline Seed rate & & $28.06 \mathrm{a}$ & $25.89 \mathrm{~b}$ & $26.42 \mathrm{ab}$ & $27.92 \mathrm{a}$ & & \\
\hline
\end{tabular}

Each means in row for one or interactions factors with different letters are significantly different at $\mathrm{P}=0.05$ using Duncan's multiple range test.

non pinching $4.68 \%$. While ash percentage for plants sowing at seed rate 0.8 $\mathrm{g} / 10 \mathrm{~m}^{2}$ didn't significantly superiors $4.95 \%$, when compared with $0.6 \mathrm{~g} / 10 \mathrm{~m}^{2}$ 4.83 it is superior on high rate sowing seed $1.0 \mathrm{~g} / 10 \mathrm{~m}^{2}$, and $1.2 \mathrm{~g} / 10 \mathrm{~m}^{2} 4.67 \%$. All interaction between the levels of factors have a significant influence on this characters and the highest percentage $5.17 \%$ obtained in pinching plants fertilized with high level of nitrogen and phosphorus and sowing at seed rate $0.8 \mathrm{~g} / 10 \mathrm{~m}^{2}$ while the lowest $4.43 \%$ for non pinched plant fertilized with high level and sowing at $1.2 \mathrm{~g} / 10 \mathrm{~m}^{2}$ rate. 
Table (6): Effect of very high levels of nitrogen and phosphorus fertilization, pinching, and Seed rate sowing on humidity percentage of Nigella sativa L. seeds.

\begin{tabular}{|c|c|c|c|c|c|c|c|}
\hline \multirow{2}{*}{$\begin{array}{c}\text { Fertilizer } \\
\text { Levels }\end{array}$} & \multirow{2}{*}{ Pinch } & \multicolumn{4}{|c|}{ Seed sowing rate $\mathrm{g} / 10 \mathrm{~m}^{2}$} & \multirow{2}{*}{$\begin{array}{l}\text { Fertilizer } \\
\times \text { pinch }\end{array}$} & \multirow{2}{*}{$\begin{array}{c}\text { Fertilizer } \\
\text { effect }\end{array}$} \\
\hline & & 1.2 & 1.0 & 0.8 & 0.6 & & \\
\hline \multirow{2}{*}{ Very High } & Pinch & $4.84 \mathrm{a}$ & $4.76 \mathrm{a}$ & $4.74 \mathrm{a}$ & $4.75 \mathrm{a}$ & $4.77 \mathrm{a}$ & \multirow{2}{*}{$4.74 \mathrm{a}$} \\
\hline & Without & $4.66 \mathrm{a}$ & $4.67 \mathrm{a}$ & $4.74 \mathrm{a}$ & $4.77 \mathrm{a}$ & $4.71 \mathrm{a}$ & \\
\hline \multirow{2}{*}{ High } & Pinch & $4.63 \mathrm{a}$ & $4.65 \mathrm{a}$ & $4.78 \mathrm{a}$ & $4.67 \mathrm{a}$ & $4.68 \mathrm{a}$ & \multirow{2}{*}{$4.70 \mathrm{a}$} \\
\hline & Without & $4.66 \mathrm{a}$ & $4.63 \mathrm{a}$ & $4.67 \mathrm{a}$ & $4.93 \mathrm{a}$ & $4.72 \mathrm{a}$ & \\
\hline \multirow{2}{*}{$\begin{array}{c}\text { Fertilizer } \\
\times \\
\text { Seed rate } \\
\text { sowing } \\
\end{array}$} & $\begin{array}{l}\text { Very } \\
\text { High }\end{array}$ & $4.72 \mathrm{a}$ & $4.72 \mathrm{a}$ & $4.74 \mathrm{a}$ & $4.76 \mathrm{a}$ & \multirow{2}{*}{\multicolumn{2}{|c|}{$\begin{array}{l}\text { pinch } \\
\text { effect }\end{array}$}} \\
\hline & High & $4.65 \mathrm{a}$ & $4.64 \mathrm{a}$ & $4.73 \mathrm{a}$ & $4.80 \mathrm{a}$ & & \\
\hline \multirow{2}{*}{$\begin{array}{c}\text { Pinch } \\
\times \\
\text { Seed rate } \\
\text { sowing }\end{array}$} & Pinch & $4.73 \mathrm{a}$ & $4.71 \mathrm{a}$ & $4.76 \mathrm{a}$ & $4.71 \mathrm{a}$ & \multicolumn{2}{|c|}{$4.73 \mathrm{a}$} \\
\hline & Without & $4.66 \mathrm{a}$ & $4.65 \mathrm{a}$ & $4.70 \mathrm{a}$ & $4.85 \mathrm{a}$ & \multicolumn{2}{|c|}{$4.72 \mathrm{a}$} \\
\hline \multicolumn{2}{|c|}{ Seed rate sowing } & $4.70 \mathrm{a}$ & $4.68 \mathrm{a}$ & $4.73 \mathrm{a}$ & $4.78 \mathrm{a}$ & & \\
\hline
\end{tabular}

Each means in row for one or interactions factors with different letters are significantly different at $\mathrm{P}=0.05$ using Duncan's multiple range test.

Table (7): Effect of very high levels of nitrogen and phosphorus fertilization, pinching, and Seed rate sowing on ash percentage of Nigella sativa L. seeds.

\begin{tabular}{|c|c|c|c|c|c|c|c|}
\hline \multirow{2}{*}{$\begin{array}{c}\text { Fertilizer } \\
\text { Levels }\end{array}$} & \multirow{2}{*}{ Pinch } & \multicolumn{4}{|c|}{ Seed sowing rate $\mathrm{g} / 10 \mathrm{~m}^{2}$} & \multirow{2}{*}{$\begin{array}{l}\text { Fertilizer } \\
\times \text { pinch }\end{array}$} & \multirow{2}{*}{$\begin{array}{c}\text { Fertilizer } \\
\text { effect }\end{array}$} \\
\hline & & 1.2 & 1.0 & 0.8 & 0.6 & & \\
\hline \multirow{2}{*}{$\begin{array}{l}\text { Very } \\
\text { High }\end{array}$} & Pinch & $4.99 \mathrm{ab}$ & 4.77 a-e & $4.99 \mathrm{ab}$ & $4.96 \mathrm{a}-\mathrm{c}$ & $4.93 \mathrm{a}$ & \multirow{2}{*}{$4.84 \mathrm{a}$} \\
\hline & Without & $4.86 \mathrm{a}-\mathrm{d}$ & $4.98 \mathrm{a}-\mathrm{c}$ & $4.56 \mathrm{c}-\mathrm{e}$ & $4.61 \mathrm{~b}-\mathrm{e}$ & $4.75 \mathrm{ab}$ & \\
\hline \multirow{2}{*}{ High } & Pinch & $4.85 \mathrm{a}-\mathrm{d}$ & $5.17 \mathrm{a}$ & $4.60 \mathrm{~b}-\mathrm{e}$ & $4.68 \mathrm{~b}-\mathrm{e}$ & $4.82 \mathrm{a}$ & \multirow{2}{*}{$4.72 \mathrm{a}$} \\
\hline & Without & $4.61 \mathrm{~b}-\mathrm{e}$ & $4.87 \mathrm{a}-\mathrm{d}$ & $4.52 \mathrm{de}$ & $4.43 \mathrm{e}$ & $4.61 \mathrm{~b}$ & \\
\hline \multirow{2}{*}{$\begin{array}{c}\text { Fertilizer } \\
\times \\
\text { Seed rate } \\
\text { sowing } \\
\end{array}$} & $\begin{array}{l}\text { Very } \\
\text { High }\end{array}$ & $4.92 \mathrm{ab}$ & $4.87 \mathrm{ab}$ & $4.77 \mathrm{a}-\mathrm{c}$ & $4.78 \mathrm{a}-\mathrm{c}$ & \multirow{2}{*}{\multicolumn{2}{|c|}{$\begin{array}{l}\text { pinch } \\
\text { effect }\end{array}$}} \\
\hline & High & $4.73 \mathrm{bc}$ & $5.02 \mathrm{a}$ & $4.56 \mathrm{c}$ & $4.56 \mathrm{c}$ & & \\
\hline \multirow{2}{*}{$\begin{array}{c}\text { Pinch } \\
\times \\
\text { Seed rate } \\
\text { sowing } \\
\end{array}$} & Pinch & $4.92 \mathrm{ab}$ & $4.97 \mathrm{a}$ & $4.79 \mathrm{ab}$ & $4.82 \mathrm{a}$ & \multicolumn{2}{|c|}{$4.87 \mathrm{a}$} \\
\hline & Without & $4.73 \mathrm{ab}$ & $4.92 \mathrm{a}$ & $4.54 \mathrm{~b}$ & $4.52 \mathrm{~b}$ & \multicolumn{2}{|c|}{$4.68 \mathrm{~b}$} \\
\hline \multicolumn{2}{|c|}{ Seed rate sowing } & $4.83 \mathrm{ab}$ & $4.95 \mathrm{a}$ & $4.67 \mathrm{~b}$ & $4.67 \mathrm{~b}$ & & \\
\hline
\end{tabular}

Each means in row for one or interactions factors with different letters are significantly different at $\mathrm{P}=0.05$ using Duncan's multiple range test.

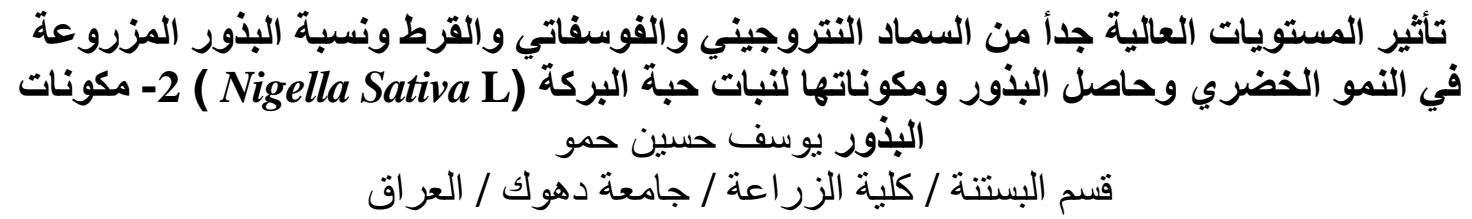




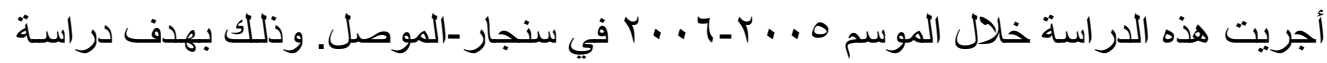

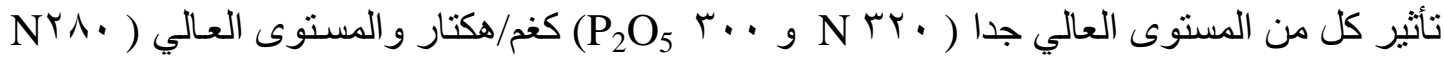

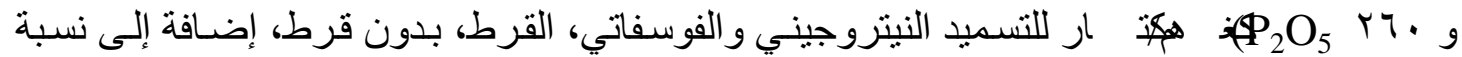

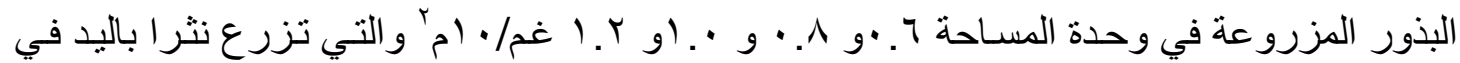

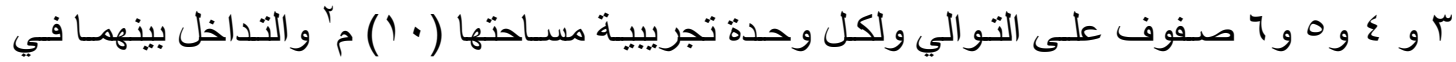

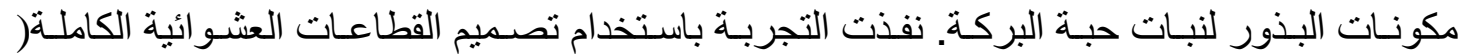
( RCBD

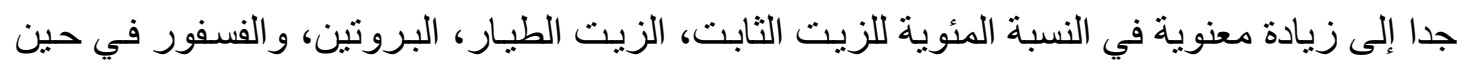

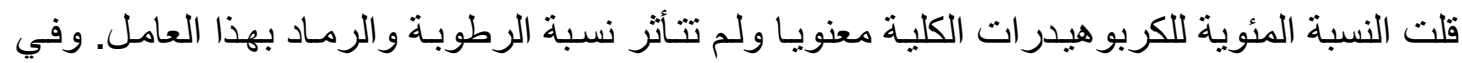
الوقت زادت فيه نسب كل من الزيت الثنابت، الكربو هيدر ات الكلية، والرمـاد معنويـا كنتيجة لإجراء عملية القرط قلت النسب المئوية لكل من الزيت الطيار، البروتين، و الفسفور .وأدى زيـادة نسبة البذور

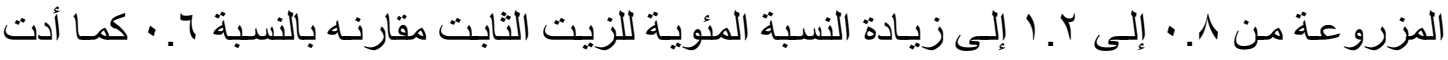

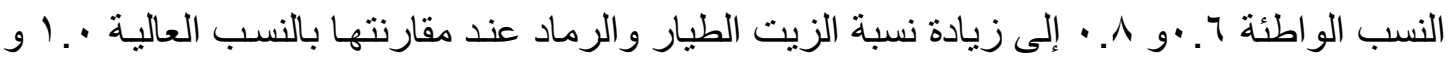

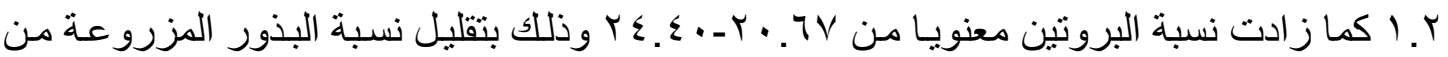

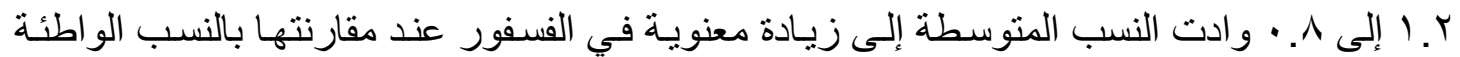

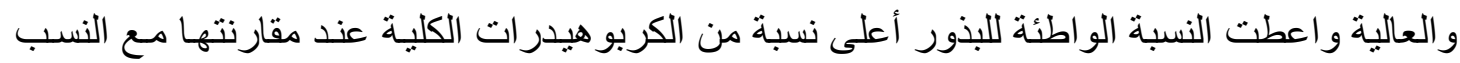

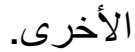

\section{REFERENCES}

AOAC (Association of Official Agriculture Chemists) (1980). "Official Methods of Analysis"13 ${ }^{\text {th }}$ Ed .Washington, d.c.

Abdullah, B. Z. A. (2006). Effect of Some Treatments on Growth and Flowering of (Cinerari Pericallis $X$ hybrida). Master thesis, College of Agriculture and Forestry, University of Mosul, Iraq.

Al-Khfagi, S. M. S. A (1986).Effect of urea sprays with several concentration and sprayed times on growth and yield of two cultivars of Capsicum annum L Master Thesis, College of Agriculture, University of Baghdad, Iraq.

Al- kaisey, M .T; A .W. Baqir and A. H. Al-Ani (1999). Chemical composition of the black cumin, (Nigella sativa L.) seeds growing in Iraq, Ibn .Alhaitham, J. for pure and app. Sci. 12(2): 55-63.

Ahmed, E. T. (1997). Influence of plant distance and some phosphorus fertilization sources on (Nigella sativa L.) plants. Assiut. J. Agric. Sick. 28 (2): 498-505.

Al-Dagawi, A. (1996). Aromatic and medicinal plant introduction encyclopedia. Madboli library. Cairo. Egypt.

AL-Khatony, Y. H. H. (2003). Effect of Some Agricultural Factors on Growth, Yield and Oil of Nigella sativa L. plants. Ph.D. Thesis. College Of Agriculture and Forest. University of Mosul, Iraq.

Asiah, A. M., A. B. Frank, L. W. Stuart., and E. S. James (1992). Growth Response of Seedlings of Flame Azalea to Manual and Chemical Pinching North Carolina "SNA Research Conference, 37.251-252. 
Atta, M. B. (2003). Some characteristics of Nigella (Nigella sativa L.) seed cultivated in Egypt and its lipid profile. Food Chem., 83: 63-8.

Bates, T. and J. Lynch (1996). Stimulation of root hair elongation in Arabidopsis thaliana by low phosphorus availability. Plant Cell Environ, 19:529-538.

Cavins, T. J., L. Greer, J. L Gibson, B. E. Whipker, and J. M. Dole (2003). Response on Majorana hortensis e of marguerite daisy (Argyranthemum frutescens) "Comet Pink" to plant growth regulators. PGRSA Quarterly. 31(1): 2-7.

Ecke, P. and O. A. Matkin (1976). The Poinsettia manual. Encinitas, California, United States, Paul Ecke Poinsettias.

El-Gamassy, A. M., K. M. El-Gamassy and F. K. Al-Sharkawy (1980). Effect of some cultural treatments on the growth and yield of sweet Margoran plants. (Majorana hortensis) Annals. Agric Sci. Fac. Agric, 25 (1 and 2):283-298.

George, O. (2001). Effect of container volume and nitrogen application on the growth of young citrus seedlings Proceedings of the Horticulture seminar on Sustainable Horticultural Production in the tropics October 3rd to 6th 2001. Jomo Kenyatta University of Agriculture and Technology, JKUAT, Juja, Kenya.

Goodwin, T. W. and E. I. Mercer (1985). Introduction to plant biochemistry Dual ed. Pergamon press, Oxford, New York.

Hammo, Y. H. and A. O. Al-Atrakchii (2006). Effect of nitrogen, phosphorus fertilizers and plant distances on growth of (Nigella sativa L.).1Vegetative growth and seed oil production. Mesopotamia J. of Agric. 34 (3): $17-26$.

Herbert, D., P. J. Philips and R. E. Strange (1971). Determination of total carbohydrates, in methods in microbiology. , J. R. Norris and D. W. Robbins (Eds) Acad, press, London and New York, 5B, chap 3.

Hanafy. M. S. C. (1984). Studies on the effect of soil type and chemical fertilizer on the growth yield and essential oil production of corianden (coriandrum sativum L.) M. Sc. Thesis . Fac of Agric Cairo Univ, Egypt.

Kizil. S. (2002). The effects of different seed rates of selected coriander (Coriandrum sativum L.) lines on yield, yield components and essential oil rate. Turkish J. Field Crops, 7: 99-105.

Kamel. D., A..E. Awad and S. R. El-Shamy (1989). The combined effect of auxine fertilization and duration treatment on viola odorate. Ann. Conf. Arab Soc. medicinal plants Res. Feb. (C.F. Ahmed, E.T (1997). Influence of plant distance assiut .J.Agric . Sci. 28 (2).

Larson, R. A. (1980). Introduction to horticulture. United States, Academic Press, Inc.

Love, J. W. (1975). Vegetative growth. In: Growing azaleas commercially. Kofranek, A. M.; Larson, R. A. Ed. University of California, United States, Division of Agricultural Science.

Matt. J. (1975). Colorimetric determination of phosphorus in soil and plant materials with ascorbic acid. Soil, Sci. 109:219-220. 
Naghdi, B. H. D., F.N. Yazdani, and M. S. Ali (2000).Seasonal Variation in Oil Yield and Composition from (Thymus vulgaris) L. under different Dense Cultivation. J. of Medicinal Plants. Naghdi@imp.irost.net.

Okeno, J. A. (2001). Effect of nitrogen for sustainable vegetable production: recent developments. Proceedings of the Horticulture seminar on Sustainable Horticultural Production in the tropics October 3rd to 6th 2001. Jomo Kenyatta University of Agriculture and Technology, Jkuat, Juja, Kenya.

Phetpradap, S., J. G. Hamptoni and M. J. Hill (1994). Effect of hand pinching and plant growth regulators on seed production of field grown hybrid dahlia. New Zealand Journal of Crop and Horticultural Science, 22: 313320.

Ranganna, S. (1985). Handbook of Analysis and Quality control for fruit and vegetable products Dual edition, TATA McGraw Hill publishing company limited New Delhi .

SAS (1989-1996). Proprietary soft ware release, 6.12 TS 020 Licensed to North Carolina state university. By SAS Institute Inc., Cary. NC. USA..

Toncer, O. And S. Kizil (2004). Effect of Seed Rate on Agronomic and Technologic Characters of Nigella sativa L. Int. J. Agri. Biol. 6 (3): 529532.

Tucker, M. R. (1999). Essential Plant Nutrients: their presence in North Carolina soils and role in plant nutrition. Agronomic Division, NCDA \& CA October: 1-9.

Uchida, R. (2000). Plant Nutrient Management in Hawaii's Soils, Approaches for Tropical and Subtropical Agriculture J. A. Silva and R. Uchida, Eds. College of Tropical Agriculture and Human Resources, Hawaii University.

Wikipedia, the free encyclopedia (2007).Plant nutrition.GNU Free Documentation License 501(c) (3) tax-deductible nonprofit charity.22:35,5 october. 